\title{
Introduction
}

Indraccolo, Lisa ; Behr, Wolfgang

DOI: https://doi.org/10.1515/asia-2014-0064

Other titles: Masters of Disguise? Conceptions and Misconceptions of 'Rhetoric' in Chinese Antiquity

Posted at the Zurich Open Repository and Archive, University of Zurich

ZORA URL: https://doi.org/10.5167/uzh-105278

Journal Article

Published Version

Originally published at:

Indraccolo, Lisa; Behr, Wolfgang (2014). Introduction. Asiatische Studien, 68(4):889-913.

DOI: https://doi.org/10.1515/asia-2014-0064 


\title{
Lisa Indraccolo and Wolfgang Behr Introduction
}

DOI 10.1515/asia-2014-0064

In a recent attempt at defining rhetoric, Joachim Knape writes:

\begin{abstract}
Rhetoric was solidly anchored in the ancient European tradition of knowledge. Nowadays the concept is indeed still familiar, though there is hardly any more clear representation of it. [...] [T] he concept of rhetoric identifies different things: a communicative practice, the related theory, a teaching subject in Communication Studies and a scientific discipline. ${ }^{1}$
\end{abstract}

Knape's words would seem to present a quite realistic assessment of the multilayered referentiality the term rhetoric has acquired through the ages as the natural result of an historical process largely driven by forces of disciplinary differentiation and continuous specialization. The term has been transformed, appropriated and adapted by several disciplines, which have imbued it with particular meanings and nuances, often without providing any explicit attempt at definition or explanation. Consequently, a wide array of different and contingent, at times overlapping, at times seemingly contradictory interpretations of rhetoric have emerged, blurring the once more tangible conceptual borders of a term, previously unequivocally associated with the Classical Greek and Roman traditions, despite all their considerable internal differentiation. This development eventually led to a widespread sense of uncertainty about what rhetoric actually means or should mean, and to what extent it is still "legitimate" to talk about it in any specific context. Before proceeding to demarcate the topic to which the present volume is devoted, an attempt seems therefore desirable to provide at least a broad clarification of the ways in which rhetoric is "generally" understood and applicable to the specific cases here presented.

1 Knape 2012 [2000]: 9. Translation is ours, unless otherwise stated.

Dr. Lisa Indraccolo: UFSP Asien und Europa, Universität Zürich, Wiesenstrasse 7-9, 8008 Zürich, Switzerland. E-mail: lisa.indraccolo@uzh.ch

Prof. Dr. Wolfgang Behr: Asien-Orient-Institut, Universität Zürich, Zürichbergstrasse 4, 8032

Zürich, Switzerland. E-mail: wolfgang.behr@aoi.uzh.ch 
To open a volume dedicated to Early Chinese 2 "rhetoric" by providing a brief account of the origins of rhetoric and its development in the West might seem prone to irreconcilable contradictions, at best traditionalist, if not downright pretentious or susceptible to "orientalism". However, it is also undeniable that the term nolens volens became indicative of a certain type or genre of oral and written communication writ large. Compared to earlier disciplinary confinements circumscribed by educational curricula, handbooks or institutional embeddings in particular cultural or historical settings, "rhetoric" is now often understood quite loosely, and used in vastly divergent academic and social contexts, which have come to include contemporary political and literary discourse. It would therefore seem useful to recall a few milestones in the history of Western rhetoric and its terminology, which has been regularly harnessed when talking about more or less similar phenomena in non-Western traditions and societies. Obviously, the present sketch is not - nor aims at being - an exhaustive or even comprehensive overview of the history of rhetoric in the West. ${ }^{3}$ The following, deliberately selective, account should rather be conceived of as an expedient device to approach aspects, developmental stages and turning points that are mirrored by case studies from the early Chinese tradition of communication, and to sketch an operational taxonomy of major trends that can be used to examine a potentially rhetorical text cross- and trans-culturally.

According to the standard Western narrative, rhetoric was primarily an effective technique of communication, originally restricted to the judicial setting, and developed by Tisias or Corax (or both) in Syracuse. Apparently, the technique was born towards the end of the fifth century B.C. out of the mundane necessity for the inhabitants of Syracuse, unaccustomed to speaking in public, to stand up in court and claim back the lands and properties that had been expropriated by the tyrants Gelo (540-478 B.C.) and Hiero I (478-467 B.C.), ${ }^{4}$ when tyranny was finally abolished in favor of the establishment of a democracy, and the last tyrant Thrasybulus (466-465 B.C.) was overthrown. Rhetoric would then have been imported into the Athenian democracy by the famous sophist Gorgias (ca. 495-380 B.C.), who came on an embassy from Leontini to ask for the help of Athens in 427.

2 Understood here, to roughly indicate the timespan from the Eastern Zhōu 周 period (770-221 B.C.) until the end of the Hàn 漢 Dynasty (206 B.C.-220 A.D.).

3 The literature on the topic is, of course, immense. For overviews of the history of Western Classical rhetoric see, e.g., Kennedy 1963, 1972, 1980, 1994; Murphy 1981, 1983 and 2005; Murphy and Katula 1995; Dominik and Hall 2010; Cole 1991; Lausberg 1963; Worthington 1994 and 2006; Schiappa 1999; Havelock 1963 and 1982; Jarratt 1991; Enos 1993 and 1995; Bizzell and Herzberg 1990. 4 Kennedy 1963: 26-51, esp. 26-27; see also van Els and Sabattini 2012: 5-7. 
It is unanimously recognized that the later fifth and the fourth century B.C. represent the "golden age" of Western Classical rhetoric. In the fourth century B.C., rhetoric was most forcefully defined by Aristotle (384-322 B.C.) in the first chapter of his Rhetoric (1355b8 seq.) as "the faculty of observing in any given case

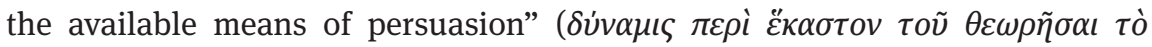

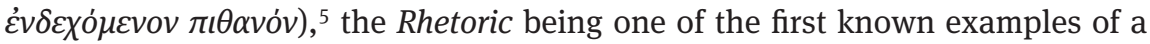
treatise on rhetorical theory, together with the anonymous Rhetorica ad Alexandrum. ${ }^{6}$ A useful and influential - though rather late - classification of the five fundamental constitutive parts of a rhetorically crafted piece is recorded in the Rhetorica ad Herennium (ca. 90 B.C.), the oldest extant systematic study of Latin rhetoric. Formerly attributed to Cicero, but of unknown authorship, the compendium was extremely popular in the Middle Ages and throughout the Renaissance period, and it was commonly used together with Cicero's (106-43 B.C.) De Inventione (ca. 85 B.C.) as teaching material. The fivefold classification turns out to be useful not only to interpret some basic changes rhetoric underwent or to refer to the way in which it has routinely been conceived in the Western world. It may also prove useful to analyze similar characteristics and turning points in the Chinese, or, indeed, many other non-Western traditions. The five fundamental parts and corresponding progressive steps to be addressed in the rhetorical process are: ${ }^{7}$

- "invention" (inventio), in which the main topic at issue and the potential means of persuasion are introduced;

- "arrangement" (dispositio), dealing with the internal organization and sequence of arguments, determined according to a mostly fixed, predictable scheme;

- "style" (elocutio), in which a broader and detailed discussion of more technical aspects of composition is carried out, usually including a specific section devoted to an extensive analysis of tropes, rhetorical figures and prosodic elements;

- "memory" (memoria), which discusses memorization strategies and mnemonic devices;

- "delivery" (actio), dealing with the performance of rhetoric, and providing practical suggestions about techniques of speech delivery, such as gestures, stance and voice.

5 Kennedy 1963: 19.

6 Although the work had been transmitted in Aristotle's corpus, it is now attributed to Anaximenes of Lampsacus (ca. 380-320 B.C.), cf. Kennedy 1963: 12.

7 For a detailed account about the different parts identified by traditional rhetorical theory see Kennedy 1963: 10-12. 
A progressively growing concern with style, ornate language (ornatus), and the sheer enjoyment evoked by beautifully crafted and elaborated pieces of oration is already discernible in Roman rhetoric. This becomes particularly evident with the flourishing of imperial rhetorical poetry, the development of didactic techniques that involved widely taught and practiced exercises such as suasoriae and controversiae, and Quintilian's (35-100 A.D.) teaching and theorizing of rhetoric, best exemplified by the twelve-volume programmatic handbook on rhetoric Institutio oratoria (ca. 95 A.D.) attributed to him. According to the famous rhetorician, a rhetor would be a "man of morals skilled in speaking" (vir bonus, dicendi peritus) and rhetoric simply "the science of speaking well" (bene dicendi scientia). ${ }^{8}$ The obsolescence of a lively and live rhetorical tradition in the West is identified by Chaïm Perelman with a progressive shift of scholarly interest in the sixteenth century, which eventually culminated in an ever more exclusive and sterile focus on style (elocutio), to the detriment of all the other aspects of rhetoric previously appreciated and codified. ${ }^{9}$ This general trend is often viewed as best represented by Pierre de La Ramée (1515-1572) and Omer Talon (ca. 1510-1562), who produced the first proper study of rhetorical figures per se and initiated a trend that would considerably influence the study of rhetoric until the twentieth century. ${ }^{10}$

In the second half of the twentieth century a renewed and periodically growing interest in rhetoric has imbued several fields of knowledge in a global effort to advance the understanding of the topic, occasionally extending its scope beyond the restricted realms of the Western Classical experience. Several attempts have been made to produce a consistent and, wherever possible, unbiased study of non-Western traditions of speech structuring, which may be eligible for being classified as "rhetorical". Among these, three major phases may be identified, according to which it is possible to classify recent studies on non-Western "rhetorical" traditions in general, and on early Chinese "rhetoric" in particular. Some of the premises in the first studies that will be briefly presented below may well look "biased" to the reader today. Yet in the decade before the appearance of Edward Saïd's (1935-2003) Orientalism in 1978 such approaches would have seemed perfectly acceptable.

Against the background of the specific cultural and academic environments that produced them, and notwithstanding several evident limitations, a coherent overview of the existing literature on the topic and of the development of the genre of comparative rhetoric will probably have to start from Robert T. Oliver's

8 Kennedy 1963: 9, 22-23.

9 Perelman 1977: 18-25.

10 Van Els and Sabattini 2012: 6. 
groundbreaking study Communication and Culture in Ancient India and China, published in 1971. In this programmatic work, Oliver stresses the necessity to read and interpret non-Western traditions "in their own terms", ${ }^{11}$ without superimposing "Western" categories of thought onto presumably different sociocultural experiences. He thus ventures an explicit attempt at providing an insider's view into "other" rhetorical traditions, taking India and China as case studies. That said, his pioneering approach is obviously limited by his incapacity to access the primary sources in Sanskrit and Classical Chinese. Consequently, he relies on translations of a very restricted selection of available texts, ${ }^{12}$ or on their descriptions in Jesuit sources - a limitation that could not fail to affect his assumptions and conclusions about the phenomena at issue. While he does not completely deny the existence of a "rhetoric" in ancient India and China despite the lack of an explicit theory of rhetoric, he eventually fails to provide the unbiased account he sets out to achieve. Oliver's approach is not immune to an essentialization of "Western" preconceptions and the inevitably ensuing dichotomization of traditions, as his final attempt at extrapolating a clear-cut list of characteristics of "Asian rhetoric" shows. Thereby, he readily assimilates all Eastern traditions into one cauldron, from which he draws nine "focal points" that are presumed to be representative of any "Asian rhetoric". No clarification is provided about the scope of "Asian" in this context, which can be indirectly deduced to include not only India and China, but also any other civilization within their sphere of influence. Such a broad generalization is questionable already for the Indian and the Chinese cases alone, which are not necessarily representative of other traditions in the same geographical area just because of geophysical proximity or cross-cultural exchanges. Moreover, not only does Oliver agree with other Western scholars such as James J. Murphy and George Kennedy about the impossibility of a proper rhetorical tradition developing in a non-democratic context, but he eventually reinforces long-standing European clichés about the alleged lack of rational and logical thought in "the" East. ${ }^{13}$

It is little wonder, then, that the following second and third phases in the development of comparative rhetoric, which in part overlap chronologically, are characterized by the flourishing of publications along the lines of Oliver's positions or against them, respectively. A complete overview of comparative studies on non-Western rhetorical traditions that were largely inspired by Oliver's work is

11 Oliver 1971: 261.

12 The same basic problem affects the work of several other renowned Western scholars, including George Kennedy. For pertinent criticism cf. Lu and Frank 1993: 448-450; Liu 1996: 332.

13 Oliver 1971: 1; 259. See also Mao 2003: 403-406; Liu 1993: 320-321. On Murphy's and Kennedy's view cf. note 21 below. 
beyond the scope of the present introduction, therefore only a selection of the most significant examples can be presented here.

The second phase is largely characterized by a generally "negative" trend in studies that draw more or less heavily upon Oliver's Communication and Culture. All these studies invariably end up denying the existence of non-Western rhetorical traditions and describe them as defective in one respect or another. A prominent case in point is John Morrison's (1972) argument against the existence of a proper indigenous rhetorical tradition in Japan, largely based on stereotypical assumptions about the hierarchical structure of the Japanese traditional family and the "Japanese national character", which would be "naturally" prone to submission and fundamentally non-argumentative, impeding the development of a proper rhetorical tradition in Japan. It is quite evident that Morrison's approach is not only hampered by sweeping Western generalizations about the "nature" of the Japanese people. It also tries hard to identify characteristics of Western Classical rhetoric within the Japanese tradition, predictably with little or no success at all - a fact which obviously does not exclude the possibility of Japan possessing $a$ rhetoric of its own.

Another typical case is Carolyn Matalene' s (1985) influential essay about the rhetoric and argumentative structure in the written compositions of Chinese ESL students. Since her research was carried out on a limited number of case studies (only 50 students were considered), it obviously presents a fairly partial view. Her rather reductive binary analysis results in a straightforward dismissal of Chinese argumentative techniques as fundamentally repetitive, imitative, oblique and somewhat incoherent, thus easily perpetuating the "deficiency" model. ${ }^{14}$

A further eminent example that needs to be mentioned is George Kennedy's famous attempt at producing a comprehensive overview of non-Western "rhetorical" traditions across time and cultures, Comparative Rhetoric - An Historical and Cross-cultural Introduction (1998). The ambitious project takes into consideration a broad variety of different communication practices and phenomena from all over the world. Starting with animal language, it presents them according to a sort of evolutionary, teleological progression. ${ }^{15}$ The main problem of Kennedy's work, as we perceive it, is his complete reliance on translations to access the diverse traditions he is studying. Furthermore, his analysis directly relies upon the

14 That is, the theory according to which "Chinese rhetoric has been little more than an appendage to Chinese philosophy and literary criticism and is theoretically, textually, and even pragmatically deficient compared with its Western counterpart [...]" (Liu 1996: 324; see 318-310). On the so-called "deficiency" model see also Mao 2003: 406-407.

15 See Mao LuMing's criticism of Kennedy’s approach (Mao 2003: 409-411, esp. 410). See also Liu 1993: 323-324. 
Western rhetorical tradition, as he deliberately resorts to the use of Greek and Roman categories to read and understand non-Western traditions. Kennedy consistently rejects the use of any existing autochthonous terminology, even in such cases where extensive metalanguage for specific devices or techniques does exist, an approach which necessarily results in several forced associations. When it comes to the Chinese case, Kennedy's generally negative assumptions about non-Western traditions are reinforced by what he identifies as the absence of a "fully developed theory, its own logical structure, and a corpus of pragmatic handbooks". ${ }^{16}$ The limitations of Kennedy's studies are quite easily understood, considering the deep influence exercised by Oliver's work, which is explicitly quoted as the "single best introduction to the subject". ${ }^{17}$

A much more sophisticated, but ultimately still dissatisfying example of this kind of approach is the extensive study by Ulrich Unger (1930-2006), Rhetorik des klassischen Chinesisch (1994). Unger, the doyen of Classical Chinese studies in the German speaking world of the twentieth century and thus clearly not hampered by the filter of translation, systematically superimposes Western rhetorical categories on early Chinese texts with the purpose of proving the existence of a Chinese rhetorical tradition qua identification of exactly the same devices and stylistic features as used in ancient Greece and Rome. The results obtained show a relatively high degree of consistency with Western rhetorical categories, though some of the figures (especially phonological and prosodic ones) predictably fail to match the Chinese case. Conversely, the fact that it is actually possible to isolate occurrences of Western rhetorical devices in early Chinese texts does not necessarily entail that they are representative of what might have been considered as "rhetorical" in Early China, or have been deliberately employed as such. One must always reckon with the possibility that they resemble only contingently what are acknowledged as proper rhetorical figures in the West. ${ }^{18}$ The arbitrary pre-selection of figures clearly constitutes a limited repertoire of the "rhetorical" means employed in Classical Chinese texts, which might have significantly diverged from the canonical list Unger employed to carry out his research.

Finally, a third phase is represented by the most recent studies that strive to engage with non-Western traditions in a more constructive way. Such are, for instance, Mary G. Garett's articles, in which the scholar provides a coherent overview of different aspects of Early Chinese polemical techniques. Garrett's work features a lively synchronic and diachronic analysis of different argumentative

16 Kennedy 1980: 7.

17 Kennedy 1998: 144.

18 See also van Els and Sabattini 2012: 8. 
practices, acknowledging specific embeddings within the major strands of Chinese tradition and openly claiming the necessity to understand "rhetoric" as a culturally based, historically contingent phenomenon. ${ }^{19}$ Another recent example in this vein is Lu Xing's Rhetoric in Ancient China, Fifth to Third Century B.C.E.: A Comparison with Classical Greek Rhetoric (1998). Here, the author underlines the importance of studying the Chinese "rhetorical" tradition on its own terms, and makes a helpful, if preliminary list of autochthonous "rhetorical" operational terms to be used in her analysis, drawn from Classical Chinese primary sources. However, although first studies questioning the reliability of the traditional classification of the so-called “one-hundred schools of thought” (băijiā 百家) in the light of the recent manuscript discoveries had started to appear in the mid-1990s, ${ }^{20}$ Lu still clings to a fairly standard interpretation of early Chinese culture and society. Ancient knowledge is portrayed as strictly organized according to separated "schools of thought", thus reproducing the traditional divisions between Confucianism, Daoism, Mohism, Legalism, and the School of Names. Moreover, her suggestions to introduce a "language of ambiguous similarity" to deal with more or less similar phenomena across cultures occasionally fails to add clarity to a realm where stricter circumscription of what is being or supposed to be compared would well seem feasible.

It may thus be argued, that, at least in the Chinese case, the attempts made so far leave room for improvement in several respects. While the present publication has no pretense to provide an ultimate solution to the thorny question of whether a "proper" rhetorical tradition existed in China or not, it is aimed at highlighting the main issues at stake, with the hope of stimulating further debate on the topic.

It is hard to deny that "rhetoric" immediately evokes the Greek and Roman worlds and the Western Classical rhetorical tradition as default associations. For this reason, the validity and pertinence of the term as applied to a non-Western context has often been questioned, ${ }^{21}$ and non-Western experiences of potentially similar phenomena have been dismissed, often before any substantial analysis or

19 See Garrett 1991. See also Liu 1993: 322.

20 See for instance Petersen 1995.

21 See for instance James J. Murphy's categorical denial of the existence of a rhetorical tradition outside Greece and Rome. According to his analysis, only democracy could have led to the development of analytical thought and, consequently, of rhetoric: "There is no evidence of an interest in rhetoric in the ancient civilizations of Babylon or Egypt, for instance neither Africa nor Asia to this day have produced a rhetoric.” (Murphy 1983: 3; see also 2013: 182). A somewhat similar view on the strict necessary correlation between the development of rhetoric and democracy is shared by Kennedy 1963: 29. Accounts of the more or less problematic attempts at studying the case of early Chinese "rhetoric" include Cai 1998, Lu/Frank 1993, Mao 2003, Liu 1996, and Mittler/Wuthenow 2008. 
comparison had been carried out. Typically, non-Western traditions have been seen as "deficient" 22 in several respects when compared to Western Classical rhetoric, which is more often than not posited as a unified, ideal, and uniquely valid template of comparison.

However, it emerges quite clearly that the underlying doxa of such approaches is somewhat reductive. Ultimately, "the answer to whether there exist non-Western rhetorical traditions rests upon how we define rhetoric." 23 In fact, the conceptual scope of the term "rhetoric" in the Classical West, while in origin identifying a geographically and historically circumscribed phenomenon, may well be extended and used as a more general label to indicate certain specific kinds of communication cross-culturally. As James Berlin underlines,

[...] a rhetoric is a social invention. It arises out of a time and place, a peculiar social context, establishing for a period the conditions that make peculiar kind of communication possible. ${ }^{24}$

Under such a broad view, the term rhetoric could flexibly encompass features that may be acknowledged as characteristic of non-Western traditions. At a closer look, the term has already undergone a somewhat similar process in the West, considering that the English term "rhetoric" is used to designate recent develop-

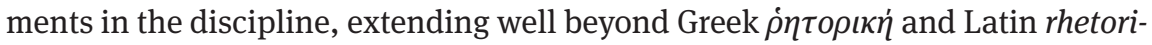
ca/e, e.g. in the case of Chaïm Perelman's (1912-1984) New Rhetoric. ${ }^{25}$ In this sense, a uni- and unequivocal conceptual correspondence between rhetoric-assuch and Classical rhetoric is already lost in what ceases to be "the" West as well.

Looking at the contributions to this volume, it may be argued that the term can be coherently applied to early Chinese polemical discourse, without such an endeavor necessarily implying subversion of the set of features that conventionally identify "rhetoric" in the Western Classical tradition. As Scott in his programmatic article "On Not Defining Rhetoric" has pointed out, "any definition of rhetoric that is taken once-and-for-all is apt to be gravely misleading". ${ }^{26}$ Taking for instance Aristotle's standard definition of rhetoric as "the faculty of observing in

\section{See note 14.}

23 Cai 1998: 11.

24 Berlin 1984: 1. Italics are ours. See also Cai 1998, esp. Chapters 1 and 5.

25 Cf. R. Weber, this volume.

26 Scott, 1973, p. 95. While the theory according to which people might share a pre-theoretical and pre-scientific innate "sense of rhetoric" seems to provide a relatively good description of the case of Early China, this rather impressionistic term might involuntarily end up reinforcing the long-held assumption of a substantial lack of rational and logical thinking in "the East". A somewhat similar argument for early Greek rhetoric is made by Schiappa (1992), according to whom 
any given case the available means of persuasion" as an operational category, it still emerges quite clearly that it is broad enough to allow for non-Western forms of effective communication to be considered as "rhetoric" in their own right. From this point of view, Greek and Roman rhetoric - with its tripartite classification (judicial, deliberative, and epideietic), as a discipline and an art taught, performed, and transmitted in the Western Classical world, practiced in the $\dot{\alpha} y o \rho \dot{\alpha}$ and the forum in a more or less democratic environment - emerges simply as a particular instantiation of the possibilities embodied by "rhetoric" as envisioned by Aristotle. No doubt, all characteristics peculiar to the Greek and Roman rhetorical tradition, if such a generalization across two intrinsically heterogeneous manifestations of rhetoric is meaningful to start with, all features which supposedly single it out and make it a unique or unrepeatable experience in human history, are truly exclusive to that specific experience. This does not eliminate the possibility, however, that a common ground of core characteristics could be shared by and a dialogue be established with other non-Western (and even Western, as the case of "New Rhetoric" suggests) traditions.

As Ralph Weber points out in his "regard oblique" on comparative approaches to rhetoric in this volume, a comparison always involves at least three elements, the two (or more) terms to be compared (in this case, the Western Classical tradition and the Chinese tradition), and the tertium comparationis (the existence of rhetoric), an aspect that is preliminary assumed to be in common and subject to scrutiny. However, while the tertium comparationis is explicitly stated, there are necessarily other aspects that are tacitly recognized as assimilating the comparanda in question to begin with. It is these aspects, constituting the precomparative tertium, that ultimately make the comparison possible. While any specific manifestation of rhetoric (or any other phenomenon) is obviously characterized by a whole set of specificalities, this does not necessitate the conclusion that there are no a priori margins for a fruitful comparison going beyond or bridging any more or less superficial differences. Such a rigid opposition is in fact somewhat paradoxical. As Weber clarifies, those aspects that are recognized as exclusively proper to one tradition or the other do not at all come in the way of comparison per se, as they rather represent the post-comparative final result of an underlying comparison made already. Otherwise, without any valid term of comparison, it would be impossible to identify which characteristics are actually exclusive to one specific tradition at all. ${ }^{27}$

an intuitive concept of rhetoric might have already existed before Plato, even if it had not found yet explicit theoretical formulation. See also Lu/Frank 2009: 453) and Cai 1998:12-13.

27 See Weber's contribution in this volume, esp. pp. 925-926 and 930-931. 
While Western Classical rhetoric is undoubtedly a superb example of a complex, highly structured and theoreticized phenomenon, it may still be fruitfully considered as just one particular manifestation of a broader phenomenon that could be operationally defined as "effective communication”. More specifically, "effective communication" could be understood as an oral-aural or written communication that is not just passively absorbed, but rather interacts with the recipient of the message, in the sense that it positively reaches its communicative goal if it concomitantly produces a certain desired effect, provokes a more or less conscious and deliberate behavioral response, a belief or conceptual change, ${ }^{28}$ or an emotional reaction with the recipient of the message.

It would seem quite incontestable that such a broadly defined phenomenon equally affects other cultures. While its practice necessarily assumes diversified contextual culture- and language-specific settings, it is also bound to show recurrent underlying features that allow the acknowledgment of a certain specific communication strategy as a particular manifestation of a multifaceted phenomenon. It is neither necessary, nor in the long run practicable to coin neologisms to define local manifestations of a phenomenon each time a new specific cultural context is faced. It often seems more fruitful to classify phenomena sharing a set of partially overlapping characteristics as particular manifestations of a broader concept, working as a sort of hypernym, the semantic field of which should be appropriately broadened to meet contextual exigencies. As it has already been remarked, the hypernymic concept of "rhetoric" as the skill and practice of effective communication, far from being a unified and homogeneous phenomenon cross-culturally, shows inner ambiguities and discontinuities even within the Western Classical tradition. Therefore, it might be more appropriate to talk about "rhetorics" instead of a monolithic "rhetoric", implicitly referring to the Western Classical tradition functioning as a presupposed yardstick against which all other potential candidates for the designation "rhetoric" are measured. As suggested by Andersen in his contribution, too broad generalizations such as "Western" rhetoric as opposed to Chinese, ${ }^{29}$ might be rather misleading if not counterproductive, suggesting an irreconcilable polarity rather than representing a manageable choice of comparanda that might lead to a meaningful comparison.

28 In cognitive psychology, the term is used to indicate changes produced over time in the acquired knowledge and preformed conceptions of a person, thus influencing her understanding, but also her response, and the way she deals with newly acquired information. It is not just a generic change of mental attitude, as this latter term rather describes the results of a conceptual change. See for instance Guzzetti/Hynd 1998 and Schnotz/Vosniadou/Carretero 1999.

29 Andersen p. 915. 
Still, a comparison between the two might be worth pursuing and even lead to unexpected results. Notice, for instance, that the lesser known history of Chinese "rhetoric" seems, to a certain extent, to follow along the lines of the Western rhetorical tradition, arguably facilitating the conceptual association between the two. For instance, "rhetoric" in Early China covers diverse techniques including what can be meaningfully considered as Chinese versions of techniques usually referred to under the label of "persuasion" in the West. Shui 說, Old Chinese *lot-s, "to plead with, blandish, cajole, exhort etc.”, as the term probably closest to the lexical field of suasio in Latin, is morphologically transparently derived from an underlying unsuffixed root * lot > shuō 說 “to speak, explain, argue”. It is an exoactive-directive formation ${ }^{30}$, fully homophonous to the verb shui 税 ( ${ }^{\star}$ lot) "to unharness, let loose", which also meant "to present a ritual robe to the dead", later generalized to "to offer a present". "To convince" would thus be to "argue in a certain direction", to "let loose" one's speech, as if one would "overwhelm" someone as important as a deceased ancestor with "a present”. In Warring States (475-221 B.C.) texts, shui are typically, albeit by no means necessarily, ${ }^{31}$ structured as a plea, usually addressed to a superior in rank and aimed at convincing the persuadee to agree on some key ethical or political issue or to assume a certain desirable role or behavior. To successfully achieve his goal, the speaker has to be sensitive to the addressee's moods and state of mind, to "read" him and understand his psychology, so that he can turn the interlocutor's innermost desires and aspirations to his own advantage. The persuader must - as Mary Garrett puts it - "appeal [...] to emotions, to enlightened self-interest, and to idiosyncratic desires" 32 , by approaching the most suitable topics in a timely manner and convincing way ${ }^{33}$, and by modulating his speech according to the audience and to the specific circumstances in which the persuasive argument is delivered. In Classical Chinese received literature, instances of shui often assume the form of elaborated dialogues conceived as written texts with an explicit persuasive intent, and they are often embedded in a more or less detailed narrative framework that contextualizes the setting and the occasion of the speech. ${ }^{34}$

30 For the model of Old Chinese phonology and morphology used here, cf. Baxter/Sagart 2014.

31 Cf. Levi 2013 for a recent compilation of scenes of debates located outside the typical palace hierarchies.

32 Garrett 1993: 112.

33 "Motivated by the self-interested desire for profit, yóu shuì employed utilitarian appeals in persuading their audiences. In speeches they made to the kings of the various states, for example, they would spell out the material gain, in terms of land, beautiful women, horses, food, and clothing. The ruler could expect benefits he would gain by adopting the proposed plan." (Lu 1998: 119). See also Goldin 1993: 5; Kern 2000: 230.

34 Crump 1964 and 1979, Kern 2000, Lu 1998, Goldin 1993. 
However, the first theoretical reference to persuasion (shui) as a proper literary genre only appears in the Medieval period, namely in Lù Jỉ's 陸績 (261-303 A.D.) Wén fù 文賦 (Rhapsody On Literature). Somewhat later, Liú Xié 劉劦思 (ca. 465-522 A.D.) in his Wénxīn diāolóng (Carved Dragons of the Textual Mind), the first extant work of literary criticism in the history of Chinese literature, also provides a detailed description of persuasion and identifies the Warring States period as the age of the maximum flourishing of shui. While there is no evidence of an explicit theory of rhetoric in the Classical Chinese tradition, and rhetoric is also neither canonized as a proper discipline nor as a distinct literary genre, examples of what may be acknowledged as "rhetorical pieces", both in prose and verse, are preserved in several early Chinese texts. These belong mostly - but not exclu-

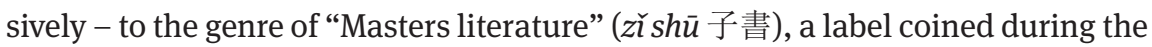
reorganization of the Imperial Library in the Hàn period (206 B.C.-9 A.D., 25-221 A.D.), an early imperial literary and bibliographical category identifying a bulk of composite transmitted texts. These consist mostly in rather heterogeneous collections of dialogues, anecdotes, sayings, or treatises that typically present a political, ethical or didactic content and, more often than not, a distinctively polemical tone. Such collections have long been taken as faithful representations of Chinese culture and society in the Warring States period. However, against the background of recently excavated manuscripts and of the consequent rereading of the image of the past conveyed by the received literature, many of these "masters" collections are meanwhile acknowledged as having reached editorial completion only during the early imperial period. Due to the process of collating, editing, and, in some cases rewriting the received literature underwent mostly during the Han period, the texts in their present form have inevitably been influenced by a certain imperial ideology that heavily influences their structure, their content, and the a posteriori interpretations of facts recorded in these texts. Although they can thus hardly be considered as directly representative of Warring States arguments and thought, these texts still provide invaluable information about polemical - possibly rhetorical - activity in pre- and early imperial China. ${ }^{35}$ Other examples of "rhetorical" pieces in the form of speeches, deliberations, memorials or remonstrances addressed to the rulers are preserved in large number in collections such as the Shüjīng 書經 (Book of Documents) or in the imperial dynastic histories, and, to a lesser degree, in Zhōu bronze inscriptions.

The imperial period witnessed a growing taste for ornate style, first represented by the Hàn fù 賦, a genre intertwining prose and poetry and variously

35 Cf. Denecke 2010. 
translated as "rhyme prose", "prose poem" or "rhapsody". ${ }^{36}$ In the early Medieval period, especially during the Six Dynasties (220-589 A.D.), the development of “parallel prose” (piánwén 駢文), a highly stylized kind of rhythmical prose characterized by strict requirements of constituent parallelism, became the prime domain of ornate language. Apart from its superb literariness and exuberant language, the fù often opens up with a debate between two or more fictional characters. It usually has a clearly didactic tone, a cleverly conceived suasory function and, ultimately, a political or polemical purpose, ${ }^{37}$ as its ideal goal is to express indirect criticism of the ruler. ${ }^{38}$ The close similarities linking the underlying purpose and dialogic structure of the fù with the genre of persuasion in pre-imperial argumentative prose would seem well worth exploring. ${ }^{39}$ In response to the indulgence in unrestrained ornamentation characterizing the fù and piánwén genres, the Táng 唐 (618-907 A.D.) and Sòng 宋 (960-1279) dynasties saw a whole debate, in which the privileged position of ornate and refined language over substance and moral engagement was harshly criticized. It is noteworthy how the exclusive understanding of rhetoric as an extreme form of elocution privileging ornate style distantly echoes the Western trend of an obsessive interest in ornate language and polished words, epitomized by literati like de La Ramée and Talon.

Since the Jìn 晉 dynasty (265-420 A.D.) several writing manuals started to appear, providing theoretical guidelines and practical instructions on how to produce vivid and lucid prose abiding by traditional rules of composition. These include, e.g., Yáo Chá’s 姚察 (533-606 A.D.) Xù wénzhāng sȟ̌ 續文章始 (Further On the Origins of Patterned Compositions), Féng Jiàn’s 馮鑒 (fl. late Táng / Former Shǔ 前蜀 dynasties, 891-925 A.D.) Xīuwén yàojué 修文要訣 (Secrets of Success in Text Ornamentation), and Chén Kuî’s 陳騤 (1128-1203) Wénzé 文則 (Principles of Textuality). The latter work features the first proper catalog of rhetorical devices and is often considered as the first systematic treatise on rhetoric in the Classical Chinese tradition. Among the other noteworthy treatises, Lü Zǔqiān's 呂祖謙 (1137-1181) Gǔwén guānjiàn 古文關鍵 (The Key to the Writing of Classical-Style Essays) and Lǐ Qíqīng’s (Lǐ Gàn) 李耆卿 (李涂) (fl. 12 ${ }^{\text {th }}$ c.) Wénzhāng jīngyì 文章 精義 (Essentials of Patterned Composition) could be mentioned. Guī Yǒuguāng’s 歸有光 (1506-1571) Wénzhāng zhǐnán 文章指南 (A Guide to Patterned Composi-

36 Von Zach 1958; Knechtges 1976.

37 On the rhetorical nature of the fù see Wilhelm 1957, Nakajima 1963, Knechtges 1972 and 1976, and Gong 1998.

38 Wilhelm 1957; Knechtges 1972.

39 A similar suasory nature of elegiac and lyric poems is also witnessed in the Western Classical tradition (Kennedy 1963: 6). 
tion), drawing on the previous manuals composed by Chén Kuí, Lü Zǔqiān, and Lǐ Qíqing, represents a kind of culmination of this genre, since it provides a guide to the correct understanding and writing of an essay, a detailed analysis of stylistic and rhetorical figures, as well as a collection of sample essays drawn from the Classical tradition. The chrestomathy illustrates the principles expounded in the theoretical sections, and, in particular, in the treatise Lùn wénzhāng ť̌ zé 論文章 體則 (On the Fundamental Principles of Composition). It underlines the primary importance of "logical structure" 40 in a written composition, that is the precondition for a coherent internal structure and exposition of arguments. ${ }^{41}$

Looking at this brief selection of the most important manuals on rules of composition, it emerges quite clearly that the Medieval Chinese and later imperial concern with rhetoric seems to focus almost exclusively on the written word, and to show an increasing interest in the study of rhetorical and stylistic devices in their own right. The progressively growing attention to the stylistic aspects of what one is tempted to call elocution mirrors a gradual shift of Chinese "rhetoric" from oratory, i.e. the practice of rhetorical performance, to a more standardized and highly self-referential meta-discourse, largely focused on the study of figures and devices. This process culminates during the Ming 明 (1368-1644) and Qīng 清 (1644-1911) dynasties with the development of the highly stylized genre of "systematic prose" (zhìi 制義). ${ }^{42}$ Better known as the famous "eightlegged-essay” (bāgǔwén 八股文), “systematic prose” was a fundamental component of the civil service examination, and required that candidates were not only able to quote the classics appropriately, but also to satisfy the demanding rhetorical requirements of the genre and to be innovative in their application. ${ }^{43}$

After this brief excursus on the history of the Chinese argumentative tradition, it might be useful to analyze the main issues raised by the attempt to define such a tradition as "rhetorical". One of the arguments why the case of "rhetoric" in Early China has always been considered controversial is that no proper handbooks or treatises on rhetoric have been preserved. This lack of textual evidence has often been equated with a failure to develop an awareness of and metadiscourse about the rules and conventions that necessarily reside at the core of such practices. Notwithstanding the lack of primary sources, which may or may not be due to failures in transmission, "rhetoric" in the sense of public oratorical practice - whether delivered orally or embedded into written discourse - may well be assumed to have played a prominent role in Early China. As the contribu-

40 Liu 1996: 327.

41 See Zheng and Tan 1980; Liu 1996: 325-329, esp. 326-328.

42 See Mittler and Wuthenow 2008: 2029-2030.

43 Cf. Des Forges 2006: 148-149. 
tions included in the present volume show, there is abundant evidence of the practice and performance of a lively oratorical activity, despite the unsystematic nature of relevant examples, scattered across the early literature. ${ }^{44}$ It is evident that any attempt at identifying and classifying rhetorical devices, or, more generally, at studying recurring patterns and stylistic and structural features of early Chinese argumentative texts ought to proceed tentatively, as any available information is embedded into larger multi-layered narratives, and may only be extrapolated indirectly. ${ }^{45}$ Even in the absence of an explicit theorization and instantiation as a "discipline", such an implicitly theorized, internalized, and eventually mastered practice would nevertheless remain a conceivable form of "rhetoric". ${ }^{46}$ Eventually, this process does not seem to be too dissimilar from what happened in the Western Classical tradition, as Andersen underlines: "rhetorical doctrine and the rhetorical inventory were extracted, so to say, from practice. And rhetorical practice itself, the systematic use of linguistic and logical resources to achieve an effect on an audience was the empirically grounded, qualified enhancement of the exploitation of the natural resources of language and thus of the mind." ${ }^{47}$

If it is assumed that "oratory is rhetoric in action" 48 and that "[r]hetoric [...] involves both theory and practice. It will be [...] more convenient to use 'oratory' in reference to actual speech and 'rhetoric' as indicating the theory or technique of speaking". ${ }^{49}$ By extension, it might be more appropriate to talk about evidence for an oratorical tradition in early Chinese texts. Though a closer investigation of this subtle distinction is beyond the scope of the present contribution, it is a potentially promising option to consider that deserves further attention. In any case, it is prima facie hardly conceivable that the variegated accounts of oratorical performances preserved as repositories of anecdotes in several early Chinese texts were not also anchored within a proper rhetorical tradition, including theory.

44 "Many early Chinese writings contain examples of what would be regarded as 'rhetorical exercises' in the European tradition [...].” (Mittler and Wuthenow 2008: 2028; cf. 2027-2030); see also Lu/Frank 1993 and Cai 1998.

45 See Lu Xing and Frank 2009: 446-450 and Cai 1998: 11-13.

46 "The fact that there was no term for rhetoric in pre-modern China, [...] that rhetoric was not theoretically defined as a distinct domain, does not mean that there was no rhetoric in practice. [...] Nevertheless, rhetoric existed in China, as a concept and as a practice, even if it had not been, for a very long time, spelled out explicitly as a theory." (Mittler and Wuthenow 2008: 2028). See also Cai 1998: 11.

47 Andersen, p. 917.

48 Worthington,1994: viii.

49 Kennedy 1963: 9. 
To be sure, there is no univocally attested and well-established term for rhetoric in the Classical Chinese tradition. The first occurrence of the Chinese xiūcí 修辭 (“to arrange words” $\rightarrow$ "polished words"), in a sense that comes close to at least one of the standard Western understandings of "rhetoric", can only be found in a rather late Medieval text, the Wénxīn diāolóng by Liú Xié, mentioned above. ${ }^{50}$ Moreover, rhetoric as an independent discipline is not established until the late nineteenth and early twentieth centuries, when the term xiūcíxué 修辭學 ("study of ornated speech") is finally introduced as a result of the development of a theoretical discourse on rhetoric. ${ }^{51}$ The discourse on "arranging words" enters China through Japanese translations of Western studies on rhetoric, in particular Kikuchi Dairoku's 菊池大麓 (1855-1917) translation of the essay "Rhetoric and Belles Lettres" of 1879.52 It is therefore quite evident that the original meaning of the term xiūcíxué 修辭學 (Japanese shüjigaku) is strictly related to a conception of rhetoric as "style", as "ornamental rhetoric" or ornate speech, and it therefore remains somewhat partial vis-à-vis its Western source.

In general, autochthonous categories and terminology should be appropriately paralleled with useful translations for those who do not master the original language, and, of course, to draw comparisons. Where autochthonous terms do not exist, and the terms that have been traditionally used to convey or translate certain concepts or phenomena that are not theoreticized and identified by a specific term within a certain tradition are partial, as in the case of xiūcí, it seems more reasonable to transgress that tradition, even if it means to employ more suitable terms from non-indigenous traditions. There is no proper overall term for "rhetoric" as such acknowledged in Early Chinese texts. Even if an Early Chinese term for "rhetoric" was identified in some manuscript at a certain point, "rhetoric" would most probably still be used to translate and convey an approximation of the meaning of the Chinese term in a Western language, though obviously the two phenomena are not interchangeable.

Another option is to adopt a Chinese term the semantic scope of which might come somewhat closer to the desired meaning, even if the tradition hasn't explicitly bestowed it with the necessary authority. For example, in order to understand Chinese "rhetoric" in its own terms, Lu Xing and David A. Frank have suggested

50 The term appears in chapter 1 'Yuándào' 原道 (1 occurrence); chapter 3 'Zōngjīng' 宗經 (1 occurrence); chapter 10 'Zhùméng' 祝盟 (1 occurrence); chapter 28 'Fēnggǔ' 風骨 (5 occurrences); chapter 43 'Fùhuì’ 附會 (1 occurrence); chapter 47 'Cáilüè’ 才略 (3 occurrences). See Shih 1959; Liu 2007.

51 Cf. Horsten 1998.

52 Mittler and Wuthenow 2008: 2028; 2035. 
the employment of the term biàn 辯 as a Chinese synonym for Western "rhetoric" ${ }^{53}$ Though their attempt is noteworthy, it is not a completely satisfying solution, since the term typically signifies only one specific polemical technique, "argumentation". It would therefore exclude the Chinese version of the technique of "persuasion" (shui 說) from a hypothetical comprehensive definition of Chinese "rhetoric", which would be more congruent with the Greek original meaning, which had scope over both techniques. Both terms are widely used to indicate the two most common polemical techniques in Chinese pre- and early imperial literature, which are considered complementary and closely interconnected skills. They are often object of a meta-discourse on polemical techniques at large, even if that discourse is not expounded in a systematic way. As Kroll has pointed out, "the Warring States topos of the itinerant philosopher intent on persuading a prince to accept his teaching was related not just to persuasion but to disputation as well", ${ }^{54}$ as "the arts of 'disputation' (pien) and 'persuasion' (shui), were ascribed to the same person as mutually connected skills." 55

Moreover, the terms biàn and shui are occasionally used as a compound (biànshui 讋說, literally “argumentation and persuasion") to designate the "rhetorical arts" ${ }^{76}$ or "rhetorical activity" in its broadest sense. ${ }^{57}$ It would seem therefore sensible to adopt this combined term (biànshui 辯說) as an operational synonym for Western "rhetoric", meant in its original Aristotelian sense (i.e. not as its later exclusive development as "elocution", "style”, belles lettres).

Using indigenous terminology, a fundamental distinction may be drawn between rhetoric as biànshui 辯說 in the sense of an acquired competency, the mastery of a set of pragmatic oratorical skills related to the effective use of language, and rhetoric as xiūcí. The latter describes rhetoric as belles lettres, as "style", eloquent but, first and foremost, the aesthetically appreciable exposition of an argument. While a perfect correspondence between a specific terminology and

53 Lu and Frank 2009: 453.

54 Kroll 1985-86: 122.

55 Kroll 1985-86: 126.

56 According to a preliminary analysis of Classical Chinese premodern "rhetorical” texts, mostly but not exclusively belonging to the genre of "masters literature", it has already been possible to identify 3 occurrences in Xúnzì 荀子, ch. 6 'Fēi shì'èr zì’ 非十二子; ch. 12 'Jūndào’ 君道; ch. 22 'Zhèngmíng’ 正名; 7 occurrences in Hánfēiž̃ 韓非子, 1.2 ‘Cún Hán’ 存韓, 2.8 ‘Bā jiān’ 八茹; 5.15 'Wáng zhǐ' 亡徵; 11.32 'Wài chǔ shuì zuǒ shàng' 外儲說左上 (2 occurrences); 16.42 'Wèntián' 問田; 19.49 ‘Wǔdù’ 五蟗; 1 occurrence in Huáinánzǐ 淮南子, 6, 'Lăn míng’ 覽冥.

57 Xúnzi 22: 272-277; see also Kroll (1985-86: 121) “The Warring States topos of the itinerant philosopher intent on persuading a prince to accept his teaching was related not just to persuasion but to disputation as well.” (p. 122). Moreover, "the arts of 'disputation' (pien) and 'persuasion' (shui), were ascribed to the same person as mutually connected skills.” (p. 126). 
the related practices across time and cultures is of course impossible, ${ }^{58}$ it could be said that the first connotation echoes the ancient European tradition of rhetoric as a pragmatic practice or $\tau \dot{\varepsilon} \chi v \eta$, while the second appeals to the later understanding of rhetoric as beautiful expository style. It is this latter somewhat problematic term that is usually employed to translate the general term "rhetoric" into Chinese.

Another critical issue is represented by the evident difficulties encountered in trying to disentangle what have been tentatively identified as the main trends characterizing early Chinese "rhetoric", i.e. "persuasive rhetoric" and "ornamental rhetoric". ${ }^{59}$ It would seem that these two aspects are not necessarily contradictory, but rather complementary. They are typically closely intertwined and overlapping in Classical Chinese texts, making it hard - if not downright impossible - to separate the more or less openly polemical tone and pragmatic character typical of a certain kind of suasive communication from a fundamental appreciation and deliberate search for refined and elaborate expressions, literary allusions, sophisticated language jokes and rhyming patterns, i.e. for "beautiful language" in general. These aspects often represent two equally fundamental and indissoluble ingredients of a felicitous rhetorical piece. Although a fresh attempt to provide an interpretation of Classical Chinese "rhetorical" trends "on their own terms", such a preliminary bipolar taxonomy appears to remain rather ambiguous, since it fails to provide a consistent frame of reference, thus requiring further adjustments.

Similarly, the operational distinction between a "literary rhetoric" and a "philosophical rhetoric", as it has been more or less successfully applied to the study of Classical Greek, Roman, and Arabic traditions, ${ }^{60}$ also seems to fail in the early Chinese case. There, a clear-cut boundary between the two disciplines was neither theoretically defined nor apparently considered a necessary requirement, and the ensuing generic ambiguity was evidently considered unproblematic. Therefore, this familiar classical dichotomy turns out to be unproductive, since what could be tentatively identified and distinguished as literary and philosophical rhetoric in early Chinese texts shows a high degree of overlap, often to the point where the two become fundamentally indistinguishable. Instead of insisting on dissecting these intricate aspects of early Chinese rhetoric, it seems more productive to admit their substantial permeability in Classical Chinese texts, and,

58 "As the meaning of terms is always culturally specific, ancient Chinese and Greek thinkers would necessarily have attached their own linguistic and cultural understanding to such terms. Therefore attempting to find exact cross-cultural correlations and linkages is futile.” (Lu 1998: 5). 59 Mittler and Wuthenow 2008: 2027.

60 See for instance Woether 2009. 
in line with the substantially pragmatic nature of "rhetoric" in Early China, to shift the focus to the communicative goals the different aspects of rhetoric seems to suggest in each textual instantiation.

What is most relevant in the Chinese case is the generally less speculative character and the strong emphasis on the goal-oriented nature of rhetoric and its power to create social change. Accordingly, rhetoric in the Chinese tradition is often understood as an effective tool for "social engineering". As such, it is considered as a powerful and dangerous instrument that should be handled with care and used with wisdom. It can deeply affect society at large through the words and deeds of the rulers, impacting not only on life conditions but also the values, morals and ethics of the entire population. Thus, rhetoric assumes a fundamental role in a wider political agenda that has the achievement of a successful government as its ultimate aim. In this perspective, it seems more sensible to suggest a tripartite classification of Chinese rhetoric based on its diverse purposes, or as "functional styles", ${ }^{61}$ keeping in mind that one or more of these aspects can - and usually does - overlap: (1) rhetoric as a $\tau \dot{x} \chi v \eta$, i.e. the pragmatic art of argumentation and persuasion (biànshui 辯說) which abides by a set of predictable communication delivery frameworks, and draws upon a shared repertoire of conventional tropes and devices according to communication circumstances; (2) rhetoric as style (elocutio) or belles lettres, i.e. the art of expressing oneself in beautifully crafted, ornate language, typically enhanced by the deliberate choice not only of words, but also of phonetic and prosodic stylistic devices, such as rhythm, rhyme patterns, alliterations, assonance etc.; (3) rhetoric as an expressive code, i.e. as a normative set of shared formal and generic conventions, proper to a specific genre within a certain tradition; in conformity with these conventions, certain topics, attitudes and feelings are expressed in a regulated, predictable, albeit at times abridged and allusive conventional ways, determining also the formal and stylistic devices that are expected to be strategically employed and appropriately displaced throughout the text.

As the topics and textual sources treated are closely related both chronologically and contextually to the earlier stages in the historical development of Chinese "rhetoric", the contributions included in the present volume predictably tend to cluster around the first (rhetoric as a $\tau \dot{\varepsilon} \chi v \eta$ ) and the third (rhetoric as expressive code) aspects of Chinese "rhetoric". They were all originally presented at the Conference "Masters of Disguise? - Conceptions and Misconceptions of 'Rhetoric' in Chinese Antiquity”, held at the Oechslin Library in Einsiedeln, Swit-

61 Galperin (1977: 32) defines functional styles as "a system of interrelated language means which serves a definite aim in communication." On the different aspects of rhetoric see also Andersen in the present volume (pp. 916-917). 
zerland, between September 4 and $62013 .{ }^{62}$ In particular, the first and the second section into which the contributions have been subdivided here group together articles that explicitly deal with internal structural patterns, particular rhetorical devices and stylistic features, as well as modes and strategies of argument construction.

The first group of articles focuses on structuring devices used to enhance argumentative force and to establish meaningful intertextual and inter-chapter connections in early Chinese texts belonging to different genres and periods. It is opened by Dirk Meyer's contribution, which provides a detailed analysis of the strategies of meaning construction at work in an early Chinese manuscript of the Tsinghua collection, `Jīn Téng 金縢 (“The Metal Bound Coffer”), with particular attention being paid to the intricate web of internal cross-references characterizing the text, which build bridges of sense connecting different sections.

Similarly, Lukáš Zádrapa’s article investigates rhetorical strategies of meaning construction employed in the Hánfēiž̀ 韓非子, highlighting linguistic and semantic cross-references and recurring patterns through the analysis of formal devices demarcating textual building blocks, deliberately positioned in such a way as to reinforce logical arguments made in selected passages of the text.

62 We wish to take the opportunity to thank all the people who made this conference a smooth and exceedingly pleasant event - the conference presenters, not represented in this volume: Chen Rudong (Beijing), Robert H. Gassmann (Winterthur), Licia Di Giacinto (Bochum), Christoph Harbsmeier (Oslo), Martin Kern (Princeton), Michael J. Puett (Harvard), Lisa Raphals (Riverside), Haun Saussy (Chicago), David Schaberg (Los Angeles), Dennis Schilling (Taipei and Munich), Suzanne Saïd (Paris), Zhou Yiqun (Stanford), Nicolas Zufferey (Geneva); the discussants Erica Brindley (University Park), Stephan Peter Bumbacher (Basel), Albert Galvany (Barcelona), Yegor Grebnev (Oxford), Paulus Kaufmann (Zurich), Richard King (Bern), Rens Krijgsman (Oxford), Kathrin Messing (Zurich), Duncan Paterson (Heidelberg), Mercedes Valmisa (Princeton), Jenny Zhao (Cambridge); our marvelous and enthusiastic hosts at Einsiedeln: Anja Buschow Oechslin, Werner Oechslin and Karin Peterhans; our student helpers Eleni Andrist, Julia Escher, Felix Oswald, Marcel Schneider, Siglinde Schnider and Yves Trachsel; the support staff at the URPP Asia and Europe and the AOI secretariat in Zurich: Dagmar Löher, Olga Rix and Roman Benz. Special thanks go to Marc Winter, who took over pressing responsibilities of one of the organizers during the conference, to the indefatigable Rafael Suter, for all the help and patience with copy editing this journal issue as well as his contribution as discussant, and to James Weaver for the careful proofreading of the whole volume and the suggestion of elegant solutions to even the trickiest stylistic problems, and to all the anonymous reviewers for their constructive comments and corrections. For generous financial support we wish to thank the Swiss National Science Foundation (SNF), the Chiang Ching-kuo Foundation for International Scholarly Exchange (CCKF), the Swiss Academy of Humanities and Social Sciences (SAG), the Swiss-Asia Society (SAGW), the Zürcher Universitätsverein (ZUNIV), and, last but not least, the URPP Asia and Europe of the University of Zurich. 
The contribution by Joachim Gentz focuses on rhetorical strategies as practice and behavior, and contributes a detailed account of one of the most cryptic texts of the Classical Chinese tradition, the Guǐgǔž 鬼古子. This text might also tentatively be considered as a handbook on the technique of persuasion, as it devotes several chapters to the treatment of specific strategies to be mastered and enacted when engaging in this rhetorical activity.

A second group of papers revolves around argumentative methods employed in order to support or exert different forms of control, either of inferiors in rank or of the reception, interpretation and transmission of a specific message. In his contribution, Matthias L. Richter underlines the ambivalent character of rhetoric, at the same time a desirable skill and a powerful weapon, by analyzing catalogs of types of rhetorical behavior. Such catalogs, often embedded in broader narratives, were expected to provide useful information for the effective recruitment of officials and guidance on how to detect potentially treacherous personalities who might have endangered the state and challenged the power of the ruler.

Christian Schwermann's contribution explores the multi-referentiality derived from the use of quotations in a selection of early imperial memorials to the throne of the Qín 秦 (221-206 B.C.) and Hàn periods. His analysis shows that quotations are not mere embellishments or expedients used to claim authority. They also have argumentative power, as they contribute to the overall development of the argument by establishing meaningful inter- and intra-textual conceptual relationships between the original text and the new context, when it is "strategically" quoted.

The third and last section groups a set of contributions which address the third aspect (rhetoric as expressive code) of Chinese "rhetoric" in different contexts, dealing with rhetorical strategies employed to establish and corroborate a specific tradition. Attilio Andreini provides a detailed account of the rhetorical construction of the prototypical antagonist par excellence of early "Confucian" teachings in the Mèngž 孟子. This is achieved through the synecdochal and symbolical form of the binomial Yáng-Mò 楊墨, in which the adversary doctrines supported by Yáng (Zhū) 楊朱 and Mò (Dí) 墨翟 are condensed in such a way as to eventually signify any contrary ethical position at large.

Oliver Weingarten's paper deals extensively with two rhetorical uses of the paradigmatic figure of Confucius, especially in a selection of dialogues where a specific formula (wú yŭ rǔ 吾語汝) is employed by the Master to address his interlocutors. The article explores the unifying power of the Confucius figure as it is used to build up consistent narratives and to integrate different anecdotes into a more coherent whole, as well as more traditional uses of the Confucius figure as that of the authoritative master dispensing wisdom and imparting a teaching to a crowd of disciples. 
Finally, Michael Nylan explores the "rhetoric of friendship" in early imperial epistolary and anecdotal literature. The trope of friendship represents the way in which, according to the tradition, specific sentiments of affection should be mediated and expressed in a socially and culturally acceptable way, abiding to a conventional set of stylistic and rhetorical rules which characterize the appropriate expressive modality in this particular literary genre. While the "rhetoric of friendship" is a fairly well attested phenomenon and literary topos in the West since Plato, it is still an almost unexplored theme in the study of Classical Chinese literature, where it represents a most welcome contribution.

\section{Bibliography}

Baxter, Willam H. / Sagart, Laurent (2014): Old Chinese: A New Reconstruction. New York: Oxford University Press.

Berlin, James (1984): Writing Instructions in Nineteenth-Century American Colleges. Carbondale, IL: Southern Illinois University Press.

Bizzell, Patricia / Herzberg, Bruce (eds.) (1990): The Rhetorical Tradition: Readings from Classical Times to the Present. Boston: Bedford Books of St. Martin's.

Cai, Guanjun (1998): A Chinese Rhetorical Tradition? Case Studies in the History of Chinese Rhetorical Theory and Practice, University of Arizona: PhD dissertation.

Cole, Thomas (1991): The Origins of Rhetoric in Ancient Greece. Baltimore: John Hopkins University Press.

Crump, James I. Jr. (1964): 戰國策 Intrigues: Studies of the Chan-kuo Ts'e. Ann Arbor: The University of Michigan Press.

Crump, James I. Jr. (1979): Chan-kuo Ts'e. San Francisco: Chinese Materials Center Inc.

Denecke, Wiebke (2010): The Dynamics of Masters Literature - Early Chinese Thought from Confucius to Han Feizi. Cambridge, MA/London: Harvard University Press.

Des Forges, Alexander (2006): "Burning with Reverence: The Economics and Aesthetics of Words in Qing (1644-1911) China”. Proceedings of the Modern Language Association 121.1: 139-155.

Dominik, William / Hall, Jon (eds.) (2010): A Companion to Roman Rhetoric. Singapore: Blackwell Publishing.

Enos, Richard Leo (1993): Greek Rhetoric Before Aristotle. Prospect Heights, IL: Waveland.

Enos, Richard Leo (1995): Roman Rhetoric: Revolution and the Greece Influence. Prospect Heights, IL: Waveland.

Galperin, Ilya R. (1977): Stylistics. Second Revised Version. Moscow: Higher School (Ministerstvo vysshego i srednego spetsial'nogo obrazovaniya SSSR).

Garrett, Mary M. (1999): “Some Elementary Methodological Reflections on the Study of the Chinese Rhetorical Tradition”. International and Intercultural Communication Annual 22: 53-63.

Garrett, Mary M. (1993): “Classical Chinese Rhetorical Conceptions of Argumentation and Persuasion”. Argumentation and Advocacy 29.3: 105-115.

Garrett, Mary M. (1993a): "Pathos Reconsidered from the Perspective of Classical Chinese Rhetorical Theories”. Quarterly Journal of Speech 79: 19-39. 
Garrett, Mary M. (1991): “Asian Challenge”. In: Contemporary Perspective on Rhetoric. Edited by

Sonja K. Foss, Karen A. Foss and Robert Trapp. Prospect Heights, IL: Waveland, 295-314.

Goldin, Paul R. (1993): "Miching Mallecho: The Zhanguoce and Classical Rhetoric”.

Sino-Platonic Papers 41: 1-27.

Gong Kechang (1998): Studies on the Han Fu. New Haven: American Oriental Society.

Guzzetti, Barbara / Hynd, Cynthia (eds.) (1998): Perspectives on Conceptual Change - Multiple

Ways to Understand Knowing and Learning in a Complex World. London: Routledge.

Havelock, Eric A. (1963): Preface to Plato. Cambridge, MA: Harvard University Press.

Havelock, Eric A. (1982): The Literate Revolution in Greece and Its Cultural Consequences.

Princeton: Princeton University Press.

Horsten, Klaus Joachim (1998): Die Lehre vom Zurechtlegen der Worte : Xiucixue -

Möglichkeiten und Regeln des Formulierens im Chinesischen: ein Beitrag zur

angemessenen Wertschätzung der chinesischen Literatur. (Chinathemen; 38). Bochum:

Projektverlag.

Jarratt, Susan C.F. (1991): Rereading the Sophists: Classical Rhetoric Refigured. Carbondale, IL:

Southern Illinois University Press.

Kennedy, George A.(1963): The Art of Persuasion in Greece. London: Routledge \& Kegan Paul.

Kennedy, George A. (1972): The Art of Rhetoric in the Roman World, 300 B.C.-A.D.300. Princeton:

Princeton University Press.

Kennedy, George A. (1980): Classical Rhetoric and Its Christian and Secular Tradition from

Ancient to Modern Times. London: Croom Helm.

Kennedy, George A. (1994): A New History of Classical Rhetoric. Princeton: Princeton University Press.

Kennedy, George A. (1998): Comparative Rhetoric - An Historical and Cross-Cultural Introduction. New York/Oxford: Oxford University Press.

Kern, Martin (2000): “'Persuasion' or 'Treatise’? The Prose Genre Shui 說 and Shuo 說 in the Light of the Guwenci leizhuan of 1779”. In: Ad Seres et Tungusos - Festschrift für Martin Gimm zu seinem 65. Geburtstag am 25. Mai 1995. Edited by Lutz Bieg, Erling von Mende and Martina Siebert. Wiesbaden: Harassowitz Verlag, 221-245.

Knape, Joachim (2012 [2000]): Was ist Rhetorik?. Stuttgart: Reclam.

Knechtges, David R. (1976): The Han Rhapsody - a study of the Fu of Yang Hsiung (53 B.C.-A.D. 18). Cambridge/London/New York/Melbourne: Cambridge University Press.

Knechtges, David R. (1972): “Narration, Description, and Rhetoric in Yang Shyong’s Yeu-lieh Fuh: An Essay in the Form and Function in the Hann Fu". In: Transition and Permanence: Chinese History and Culture - A Festschrift in Honor of Dr. Hsiao Kung-ch'üan. Edited by David C. Buxbaum and Frederick W. Mote. Hong Kong: Cathay Press, 359-377.

Kroll, Juri L. (1985-86): “Disputation in Ancient Chinese Culture”. Early China 11/12: 119-145. Lausberg, Heinrich (1963): Elemente der literarischen Rhetorik. München: Max Hueber Verlag. Levi, Jean (2013): “Les lieux de débats en Chine ancienne: écoles, routes, académie, palais”. Études chinoises 32.1: 39-75.

Liu Yameng (1996): “To Capture the Essence of Chinese Rhetoric: An Anatomy of a Paradigm in Comparative Rhetoric". Rhetoric Review 14.2: 318-335.

Lu, Xing (1998): Rhetoric in Ancient China, Fifth to Third Century BCE. Columbia, SC: University of South Carolina Press.

Lu, Xing / Frank, David A. (1993): “On the Study of Ancient Chinese Rhetoric/Bian辩”. Western Journal of Communication 57.4: 445-463. 
Mao, LuMing (2003): “Reflective Encounters: Illustrating Comparative Rhetoric”. Style 37.4: 401-425.

Matalene, Carolyn (1985): “Contrastive Rhetoric: An American Writing Teacher in China”. College English 47: 789-808.

Mittler, Barbara / Wuthenow, Asa-Bettina (2008): "Rhetoric and stylistics in East Asia". In: Rhetorik und Stylistik. Ein internationales Handbuch historischer und systematischer Forschung, Bd. 1. Edited by Ulla Fix, Andreas Gardt and Joachim Knape. Berlin/New York: Walter de Gruyter, 2027-2039.

Morrison, John L. (1972): “The Absence of a Rhetorical Tradition in Japanese Culture”. Western Speech 36: 89-102.

Murphy, James J. (1981): Rhetoric in the Middle Ages. A History of Rhetorical Theory from St. Augustine to the Renaissance. Berkeley: University of California Press.

Murphy, James J. (ed.) (1983): A Synoptic History of Classical Rhetoric. Davis, CA: Hermagoras Press.

Murphy, James J. (2005): Latin Rhetoric and Education in the Middle Ages and Renaissance. Aldershot, Hampshire/Burlington, VT: Ashgate Publishing.

Murphy, James J. / Katula, Richard A. (eds.) (1995): A Synoptic History of Classical Rhetoric. $2^{\text {nd }}$ Edition. Davis, CA: Hermagoras Press.

Nakajima Chiaki 中島千秋 (1963): Fu no seiritsu to tenkai 賦の成立と展開. Matsuyama: Seki Yōshiten Insatsujo.

Oliver, Robert T. (1971): Communication and Culture in Ancient India and China. Syracuse: Syracuse University Press.

Perelman, Chaïm (1977): L'empire rhétorique. Rhétorique et argumentation. Paris: Librairie philosophique J. Vrin.

Petersen, Jens $\emptyset$. (1995): “Which Books did the First Emperor of Ch'in burn? On the Meaning of Pai Chia in Early Chinese Sources". Monumenta Serica 43: 1-52.

Saïd, Edward W. (1978): Orientalism. London: Random House.

Schiappa, Edward (1999): The Beginnings of Rhetorical Theory in Classical Greece. New Haven/ London: Yale University Press.

Schnotz, Wolfgang / Vosniadou, Stella / Carretero, Mario (eds.) (1999): New Perspectives on Conceptual Change. Bingley, UK: Emerald Group Publishing Limited.

Scott, Robert L. (1973): “On Not Defining 'Rhetoric'”. Philosophy and Rhetoric 6: 81-96. Unger, Ulrich (1994): Rhetorik des klassischen Chinesisch. Wiesbaden: Harassowitz.

van Els, Paul / Sabattini, Elisa (2012): “Introduction. Political Rhetoric in Early China”. In: Political Rhetoric in Early China. Special issue of Extrême-Orient, Extrême-Occident 34. Edited by Paul van Els and Elisa Sabattini, 5-14.

von Zach, Erwin (1958): Die chinesische Anthologie. Übersetzungen aus dem Wen hsüan. Cambridge, MA: Harvard University Press.

Wilhem, Hellmut (1957): “The Scholar's Frustrations: Notes on a Type of 'Fu'”. In: Chinese Thought and Institutions. Edited by John K. Fairbank. Chicago: Chicago University Press, 310-319.

Woether, Frédérique (ed.) (2009): Literary and Philosophical Rhetoric in the Greek, Roman, Syriac and Arabic World. Hildesheim: Ohlms.

Worthington, Ian (ed.) (2006): A Companion to Greek Rhetoric. Singapore: Blackwell Publishing. Worthington, Ian (ed.) (1994): Persuasion: Greek Rhetoric in Action. London: Routledge. Zhèng Diàn 郑奠 / Tán Quánjī 谭全基 (eds.) (1980): Gǔ Hànyǔ xiūcíxué zīliào huỉbiān 古汉语修 辞学资料汇编. Běijīng: Shāngwù Yìnshūguăn. 